\title{
A high incidence of non-cavity nesting in an introduced population of House Sparrows suggests that the species should not be constrained by cavity-nest site availability
}

\author{
Elizabeth Louise Sheldon ${ }^{*}$ [D and Simon Charles Griffith
}

\begin{abstract}
Background: The House Sparrow (Passer domesticus) has undergone dramatic population declines in many parts of Europe. It has been widely hypothesised that a lack of cavity nest sites has contributed to this decline. However the idea of the House Sparrow being nest site limited is somewhat incompatible with the long history of nest site plasticity in the species.
\end{abstract}

Methods: The nest-site selection in a population of non-native House Sparrows introduced to Australia from Europe just over 150 years ago was characterised. The prevalence of non-cavity nesting was quantified, and nest-site selection in terms of landscape and nesting structure were described.

Results: Flexible nesting behaviors were reported over a range of different landscapes and a surprisingly high rate of nesting in vegetation (43\%) was documented. Most nests found in vegetation were not in cavities, but were woven into the foliage and supported by branches and stems.

Conclusion: The high rate of vegetation nesting indicates that in this introduced population, the House Sparrow is unlikely to be constrained by cavity-nest site availability. The high degree of nest site plasticity in the Australian population may suggest that European House Sparrows have the potential to shift away from their proclivity for cavity nests. Future work in Europe should examine the incidence of non-cavity nesting in House Sparrows more closely, and perhaps reconsider the idea that House Sparrows are nest-site constrained.

Keywords: Passer domesticus, Cavity nests, House Sparrow decline, Nesting plasticity

\section{Background}

Although the House Sparrow (Passer domesticus) has been introduced to many parts of the world, and is now one of the most globally distributed of all birds (Pimentel et al. 2005; Shochat et al. 2010), it has become a species of conservation concern in parts of its native range (Summers-Smith 2003; Robinson et al. 2005). Throughout Northwest Europe, House Sparrow population declines have been abrupt and widespread, with the species currently on the red list of conservation concern in the UK

*Correspondence: elizabeth-louise.sheldon@students.mq.edu.au Department of Biological Sciences, Macquarie University, Sydney, NSW 2109, Australia
(Crick and Siriwardena 2002). Whilst the cause of the decline remains unclear, one suggestion has been that an increased prevalence of modern or renovated buildings has reduced the availability of crevices for nesting (Shaw et al. 2008). An increasing number of studies have cited nest site limitation as the leading (Dandapat et al. 2010; Balaji 2014; Nath et al. 2016) or contributory cause of House Sparrow population declines (Summers-Smith 2003; Goyal 2005; Anderson 2006; Ghosh et al. 2010; Balaji et al. 2013; Singh et al. 2013; Paul 2015). However, the idea of the House Sparrow being nest site limited is somewhat incompatible with the long history of nest site plasticity in the species. 
Whilst nesting behaviour in passerines generally shows a high degree of evolutionary conservatism (Price and Griffith 2017), the House Sparrow has always been recognised as a species that shows flexibility and innovation (Summers-Smith 1963; Martin and Fitzgerald 2005; Anderson 2006). House Sparrows have been reported to excavate cavities for nesting in the ground and in branches (Pitman 1961; Ivanitzky 1996), usurp and modify other birds' nests, nest in the walls of nests of other larger birds (see Anderson 2006 for a review), nest in hornets nests (Bent 1958), hay bales (Werler and Franks 1975), burrows (Chmielewski et al. 2005), billboards (Burrage 1964), hanging clothing (Sharma 1995), and moving machinery (Tatschl 1968; Weber 1976). In Asia, rocky cliffs have been reported as a common nesting site (Summers-Smith 1963; Schmidt 1966). Further, tree nesting has been considered as an alternative nesting option used when building cavities are limited due to inter-specific competition from the Tree Sparrow (Passer montanus) (Morris and Tegetmeier 1896; Summers-Smith 1963). Tree-nesting has also been reported following high population densities of invasive House Sparrows after their introduction to the USA (Barrows 1889).

Here, we aim to describe House Sparrow nesting behavior in an introduced, Australian population of House Sparrows. The House Sparrow was introduced into Australia from Europe in 1862 and its population has become established across the eastern half of the continent (Andrew and Griffith 2016). Australian House Sparrows live in heavily human-modified environments in urban and rural settings, however the Australian environment has different climates, predators, and competitors from the natal range. These ecological differences likely presented novel challenges for colonising House Sparrows, however the population's successful establishment and expansion suggests that these sparrows effectively adapted nesting (and other) behaviours to their new environment. In this study, we aim to quantify the frequency of House Sparrow nests in Tasmania (Australia) over rural and urban habitats with different levels of building cover, and describe the height and location of each nest. Describing nesting behaviours of House Sparrows from a recently introduced population such as this can provide insights into either the pre-existing plasticity of House Sparrow nesting behaviour, or its potential to respond to local selection over a relatively short period of time ( 150 years). Understanding how House Sparrows have responded to novel nesting challenges in their introduced range may also provide insights into how House Sparrows may respond to reported nest site alterations (i.e. cavity nest site limitations) in their native range (Wotton et al. 2002).
In addition to describing House Sparrow nesting behaviour in Tasmania, we also aim to provide a summary of research relating to House Sparrow nesting restrictions and population trends. We aim to highlight the difference between studies that infer House Sparrow population trends from nest-site availability/selection surveys, and studies that measure population trends and relate these measures to nest site availability/selection surveys. This may help to clarify a distinction between research that focuses on the availability of preferred nest sites and research that focuses on the availability of nest sites that are a critically limiting resource affecting House Sparrow population size.

\section{Methods}

Fieldwork was conducted at a number of locations throughout Tasmania during the Austral spring and early summer (October-December) in 2015. Sites were selected using a stratified sampling technique to ensure that only habitats suitable for House Sparrows were included in the study. We targeted areas where sparrows were known to be living and for which we could gain access by prior communication with landowners and Bird-Life Tasmania members. As a result, we identified and worked at 92 focal sites throughout Tasmania, including farms, horse stables and residential houses in urban, suburban and rural settings. At each site, we systematically searched for nests within the focal site, and along random transects in the area surrounding the focal site. We had no prior knowledge of House Sparrow presence in the areas adjacent to the focal site, although we had asked landowners whether sparrows were found in the area. Surrounding sites were generally along streets and paths within $500 \mathrm{~m}$ of the focal site.

We searched for active House Sparrow nests primarily by observing parental behaviour around the nest, including: males singing from around the nest; construction of the nest; or visits to provision nestlings. Subsequent inspection and the finding of eggs or nestlings confirmed active nests. Although site selection was initially directed by the presence of House Sparrows on the property, at each site our searchers tried to cover all likely possibilities for nesting. We searched for House Sparrow nests by looking in every accessible building, appropriate flora (e.g. trees, bushes, hedges, and shrubs), and other structures (sheds, hollow posts, carports, etc.) around the site. We moved through the area surrounding the focal site at a slow walking pace, and observed buildings and flora for House Sparrow nesting activity by walking along pavements, paths, roads, and along field/park boundaries. We also requested access to private gardens when they restricted our observations (however we did not 
record the frequency with which we were granted garden access).

Using aerial digital images (Google maps), we categorised the percentage of building cover within $500 \mathrm{~m}^{2}$ of the 92 sites. To do this we divided the $500 \mathrm{~m}^{2}$ area around the site into $5 \times 5$ grids, and visually estimated the percentage of each grid that was covered with buildings rounded to the nearest 5\%, which described 20 different levels of building cover over which House Sparrows could nest. We used the average of these measurements to provide each site with a percentage of building cover, i.e. an estimation of urbanisation.

Once an active nest was identified we estimated a number of nest-site characteristics; nest height from ground, proximity to other nests and buildings, and the height of the highest and average structure within an estimated $50 \mathrm{~m}$ diameter of the focal nest. Measures of the nesting vegetation included: the clear bole height (a perpendicular measure of the distance from the base of the tree to the first living branch on the trunk), the canopy height, the percentage of the vegetation canopy missing (estimated in the field from four cardinal directions) and the canopy volume (obtained by multiplying $\pi$ by the square of the crown radius and canopy height). The trunk diameter at breast height of the majority of hedges with nests could not be estimated. We estimated the highest point of the vegetation or building that a nest was found in, and the height of the nest from the base of the vegetation/ building. The distance from the nest to the nearest building and road was also estimated.

We quantified the frequency of nests found at each of the 25 different levels of building cover, and the frequency of nests found in particular locations. We ensured to include vegetation as potential nesting sites, as although trees and hedges are documented to be used by House Sparrows for nesting, their inclusion into nesting surveys is extremely limited (see discussion). We also quantified the frequency of nests found within a particular distance from the nearest conspecific nest.

We used a linear regression analysis to test whether the 'percent of building cover' could predict the number of nests found per $\mathrm{km}^{2}$. A binomial logistic regression was also performed to ascertain the effects of 'percent of building cover', 'distance to the nearest road (m)', and 'the average structure height in a $50 \mathrm{~m}^{2}$ area' on the likelihood that vegetation or a building was used to nest in.

We used an independent $t$ test to test (1) whether there is a significant difference between the number of nests per individual vegetative structure and individual building, (2) whether buildings used to nest in are significantly higher than vegetation, and (3) whether vegetation nesting heights are higher than building nest heights.

\section{Results}

A total of 309 active House Sparrow nests, distributed across the 92 study sites, were found. In total, 133 (43\%) nests were found in vegetation; of these, 131 (42.4\%) were in tree/hedge branches supported by fine, densely entangled twigs, stemming off a main branch, and $2(0.6 \%)$ were found in tree cavities. Overall $171(55.3 \%)$ nests were found in buildings; of these, 93 (30.1\%) were found under eaves or in walls and $70(22.6 \%)$ were found under roofing structures such as tiles (generally in the open space between curved tiles and gutters); 4 (1.3\%) were found in chimneys, and $4(1.3 \%)$ were found in other structures; a hollow post, two sign poles and an abandoned vehicle engine (Fig. 1). Finally, 5 (1.6\%) nests were found in wall/fencing climbers, and we refrained from ascribing these to either buildings or vegetation. The characteristics of nest vegetation varied greatly (Table 1), however dense trees/bushes were a common feature, as indicated by the substantial average canopy volume, average low percentage of canopy missing, and the average low clear bole height (Table 1).

A linear regression was calculated to predict the number of nests per $\mathrm{km}^{2}$ based on the percent building cover. A significant regression equation was found $\left(F_{1,13}=12.383, p=0.004\right.$, with a $R^{2}$ of 0.508 , indicating that the reduced building cover was associated with an elevated number of nests found per $\mathrm{km}^{2}$. The number of nests found per $\mathrm{km}^{2}$ decreased by 3 nests for each $20 \%$ of building cover increase (Fig. 2). We acknowledge that surveillance differences experienced between built up and rural areas (e.g. a potentially reduced detection of nests in vegetation of built up areas due to limited access to some private properties) could affect this result.

The binomial logistic regression model explained only $4.5 \%$ (Nagelkerke $R^{2}$ ) of the variance in nesting location, and correctly classified $65.5 \%$ of cases. The likelihood that a nest was in vegetation instead of a building was not associated with the height of the average surrounding structure; the proximity of the nest to a road; or the level of building $\left(x^{2}=3.625, p=0.305\right)$. Details of the average nest heights, and surrounding landscape features can be found in Table 2.

Overall, the majority of nests $(54.9 \%)$ were between 1 and $5 \mathrm{~m}$ away from the nearest conspecific nest (Table 3). As building cover increased, the distance between nearest nests also increased (Pearson's correlation, $r=0.359$, $p<0.001, n=206$ ), i.e. nests seem to be less aggregated in areas with a higher density of buildings.

We identified 71 separate vegetative structures that contained nests, and 83 buildings. Of the 71 trees/ bushes in which active nests were identified, on average, $2.25 \pm 0.21$ (SEM) nests were found in each vegetation structure (range 1-10). For the 83 buildings in which 


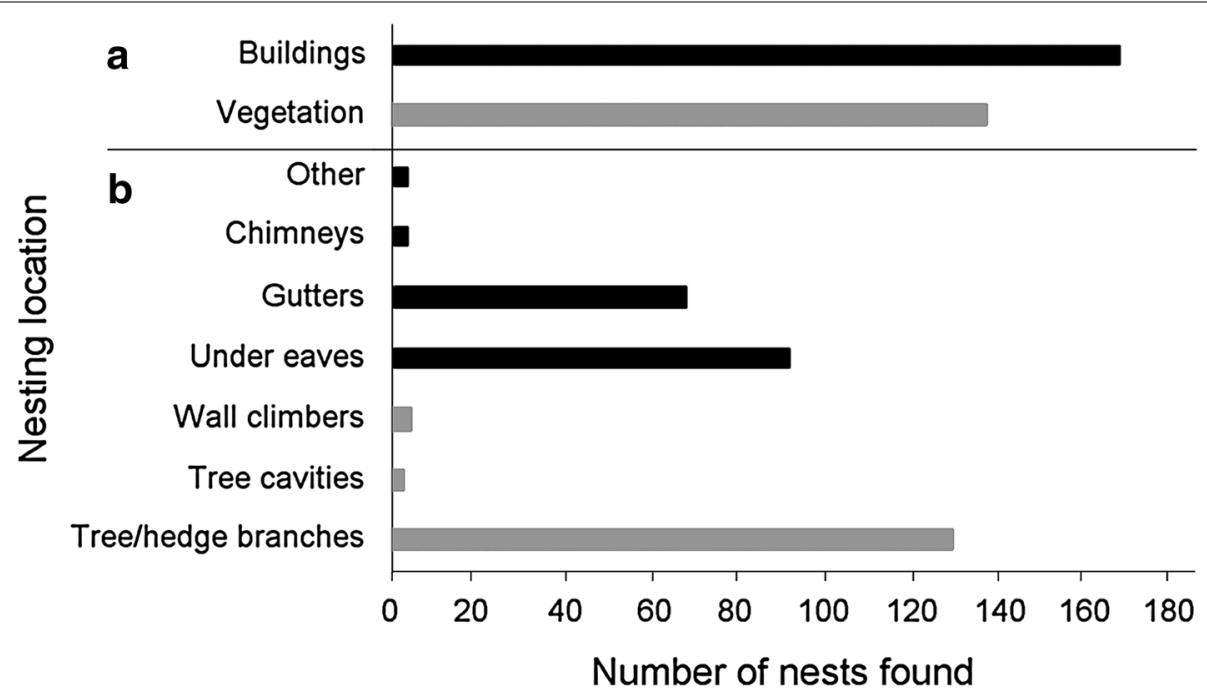

Fig. 1 The frequency of nests found at different locations; a the total number of nests in buildings and vegetation, $\mathbf{b}$ the frequency of nests in different locations within the trees (grey bars) and buildings (black bars)

Table 1 The characteristics of vegetation used by House Sparrows to nest in

\begin{tabular}{lllll}
\hline Vegetation characteristics & Mean & SEM & Range & $\boldsymbol{n}$ \\
\hline Trunk diameter at breast height $(\mathrm{cm})$ & 3.63 & 2.68 & $0.2-17$ & 110 \\
Clear bole height $(\mathrm{m})$ & 0.54 & 0.06 & $0-3.5$ & 131 \\
Canopy height $(\mathrm{m})$ & 4.31 & 0.35 & $0.1-23$ & 131 \\
Canopy missing $(\%)$ & 25 & 1.56 & $10-90$ & 131 \\
Canopy volume $\left(\mathrm{m}^{3}\right)$ & 47.3 & 6.9 & $1.1-263.1$ & 131 \\
\hline
\end{tabular}

active nests were located, on average $1.78 \pm 0.16$ nests were found per building (range 1-8). There was a trend for the mean number of nests per vegetation/bush to be higher than the mean number of nests per building, however this trend was not significant (independent $t$ test; $t\left({ }_{152}\right)=1.82, p=0.071$ ) (Table 4). The buildings used for nesting were not significantly higher than the vegetation used for nesting $t\left({ }_{307}\right)=0.127, p=0.899$ (Table 4). The mean nest height was however significantly higher in buildings than in vegetation $t\left({ }_{305}\right)=-4.64, p>0.0001$ (Table 4).

\section{Discussion}

Nesting in the branches of trees and bushes (rather than tree or building cavities) has been considered an uncommon behavior by House Sparrows (Summers-Smith 1963; Van der Elst 1981). However, we could only find three 'House Sparrow nesting studies' in the literature that include both buildings and vegetation as potential nesting sites, and quantify House Sparrow nest-sites randomly over different environments (Kulczycki and
Mazur-Gierasinska 1968; Indykiewicz 1991; Salek et al. 2015). Other papers that have aimed to characterise House Sparrow nesting only provide descriptive generalisations of nesting locations, isolated examples of rare/ unusual nesting sites, the frequencies of nests found in sought after locations, or the frequency of unoccupied, potential nest sites (e.g. Summers-Smith 1958; Heij 1985; Imboma 2014; Peach et al. 2015; Nath et al. 2016). For example, a study from urban India (Guwahati) found that the majority of House Sparrow nests were in rolling shutters, and close to walls associated with a pipe (Nath et al. 2016), however the study did not consider or sample vegetation as potential nesting sites at all.

When we compared Tasmanian House Sparrow nesting locations in the present study to the nest locations documented in other studies (e.g. Kulczycki and MazurGierasinska 1968; Indykiewicz 1991; Salek et al. 2015), the most notable difference was the proportion of nests supported by branches/stems in vegetation. Two studies from Poland (Kulczycki and Mazur-Gierasinska 1968; Indykiewicz 1991) found 0 to $19 \%$ of nests in vegetation over urban, suburban and rural areas, compared to $43.5 \%$ in the present study. The study by Salek et al. (2015) in the Czech Republic similarly found only $2.4 \%$ of House Sparrow nests in vegetation, with the large majority being under roof tiles (80\%) and in building crevices (17.5\%). The lack of vegetation nesting in the Polish studies could indicate temporal differences in the nesting habitats of House Sparrows; the Polish studies are 48 and 25 years older than the present study (Kulczycki and MazurGierasinska 1968; Indykiewicz 1991), and over this time period habitat modifications (e.g. building renovations) 


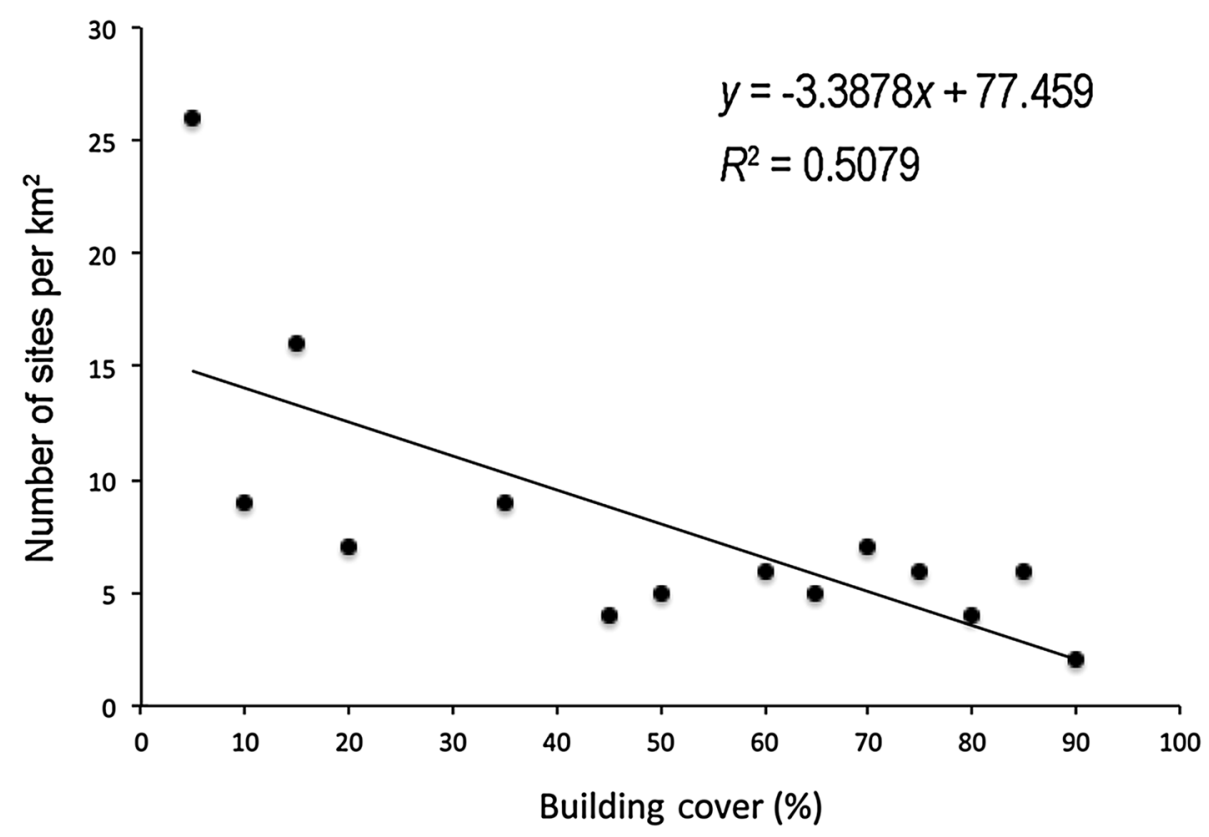

Fig. 2 A significant relationship exists between the number of sites per $\mathrm{km}^{2}$ and the percent building cover

Table 2 The height of House Sparrow nests, and the structure they were in and near

\begin{tabular}{lcr}
\hline Variable & Mean ( \pm SEM) & Range \\
\hline Nest height $(\mathrm{m})$ & $3.25(0.09)$ & $0.75-10$ \\
Nest structure height $(\mathrm{m})$ & $4.78(0.17)$ & $1.2-2.4$ \\
$\begin{array}{l}\text { Nest height as a percentage of structure } \\
\quad \text { height (\%) }\end{array}$ & $71.9(0.01)$ & $12.5-100$ \\
Average structure height within $50 \mathrm{~m}^{2}(\mathrm{~m})$ & $5.5(0.19)$ & $2-25$ \\
Highest structure within $50 \mathrm{~m}^{2}(\mathrm{~m})$ & $14.6(0.4)$ & $3-30$ \\
\hline
\end{tabular}

Table 3 Proximity of each nest to the nearest conspecific nest $(n=206)$

\begin{tabular}{ll}
\hline Nearest nest $(\mathbf{m})$ & Frequency of nests $(\%)$ \\
\hline$<1$ & 12.1 \\
$1-5$ & 54.9 \\
$5-15$ & 18 \\
$15-30$ & 7.8 \\
$>30 \mathrm{~m}$ & 8 \\
\hline
\end{tabular}

Some concealed nests and nests detected indirectly (e.g. through parental provisioning) were not included in this analysis, as the nearest nest could not be detected or accurately estimated

may have impacted nesting choices. Ecological differences between introduced Tasmania and native European environments could also have altered selection pressures driving nest site selection differences. Nonetheless, the detection of high levels of vegetation nesting in Tasmania necessitates accurate, and current descriptions of nest-site selection in declining, native populations. This will clarify whether House Sparrows can generally circumvent the effects of cavity limitation by nesting in vegetation, or if this behavior is unique to introduced populations.

We found more House Sparrow nests in areas with lower building cover; however building cover did not affect the probability of finding a nest in vegetation or a building. Further, we found House Sparrow nests to be less aggregated as building cover increased, and more nests were found per site in areas with lower levels of building cover than more built up areas. These results suggest that rural 'hot spots' are supporting much of the nesting in Tasmania. However, given that nesting in vegetation or a building is not dependent on building cover, it is unclear whether the high incidence of rural nesting is due to the availability of suitable nest sites, or the quality of the surrounding habitat for sparrows (e.g. feeding and predator avoidance opportunities) (Chamberlain et al. 2007). We found that House Sparrow nests tend to be higher in buildings compared to nests built in vegetation (however House Sparrows do not tend to nest in the highest available nest site in an area), and House Sparrows tend to nest in dense, bush-like vegetation. These results suggest that protection from predators and nesting support via dense bushes, and building crevices are 
Table 4 Independent $t$ test results for the effects of nesting in vegetation compared to a building on three dependent variables (significant results indicated by italics)

\begin{tabular}{|c|c|c|c|c|}
\hline \multirow[t]{2}{*}{ Dependent variables } & \multicolumn{2}{|l|}{ Structure } & \multicolumn{2}{|c|}{ Independent $t$ test } \\
\hline & Vegetation ( \pm SEM) & Building ( \pm SEM) & $t$ value (df) & $p$ value \\
\hline Mean number of nests per structure & $2.25(0.21)$ & $1.78(0.17)$ & $1.82(152)$ & 0.071 \\
\hline Mean nest height in structure & $2.76(0.14)$ & $3.61(0.12)$ & $-4.64(305)$ & $>0.001$ \\
\hline Mean structure height & $4.8(0.35)$ & $4.76(0.15)$ & $0.127(307)$ & 0.899 \\
\hline
\end{tabular}

important criteria for nest site selection in both vegetation and buildings for the House Sparrow.

As House Sparrows were introduced to Tasmania, the potential exists for vegetation nesting in this environment to be a result of the invasion process, or enemy release. Vegetation nesting behaviours may be selected against in Europe, as squirrels, predatory birds and domestic cats are likely to decimate the majority of tree-nesting attempts. However, these pressures are not alleviated in Tasmania where predatory threats from snakes, domestic cats, possums, and predatory birds are common. Additionally, although it is possible, it seems unlikely that the Australian flora has structural traits more conducive to House Sparrow nesting (especially given the sparse foliage of native Eucalypts), and sparrows were found to nest in both native and invasive bushes. Finally, elevated levels of aggression (Duckworth and Badyaev 2007), and behavioural flexibility (Wright et al. 2010) have been reported to facilitate range expansion in invasive bird populations (Duckworth and Badyaev 2007). Indeed, invasive House Sparrows are known to displace native birds from their nests throughout the USA (Shochat et al. 2010) and are also known to be more exploratory than native House Sparrows (Martin and Fitzgerald 2005). Such behaviours may have facilitated the establishment of previously rare nesting habits, i.e. nesting in the branches of trees, in the Australian environment. Recent nest site quantifications from the House Sparrow's native environment are necessary to enable comparative studies to clarify whether nesting flexibility in Tasmania is a characteristic of invasive birds, or of House Sparrows in general. However, given the House Sparrow's propensity to nest in varied environments in its native range, we believe the adoption of vegetation-nesting is an additional example of pre-existing nest site plasticity in this species.

We identified several studies in the literature that cite building-cavity limitation as a key parameter in influencing House Sparrow abundance (Table 5). However, on closer examination, most of these studies provide little conclusive proof that the availability of building cavities is a key determinant of reproductive success and population trends (see Table 5a). The few studies available that have focused directly on the effects of nest site availability on the population size of House Sparrows have not been able to find an association (see Table $5 \mathrm{~b}$ ). Consequently, demonstrating that the House Sparrow has a preference for nesting in building cavities does not provide clear evidence that these sites are declining, or a critically limiting resource affecting population sizes. A more comprehensive understanding of House Sparrow nesting is necessary before predictions on the effects of nest-site limitations can be considered to play a role in the population decline of this species.

There are clear challenges involved in measuring the number of small, inconspicuous crevices of all buildings in an area, especially as the number of crevices differs temporally as well as spatially due to the transient nature of building renovations and deteriorations. We have highlighted that the number of crevices should not necessarily relate to the number of suitable nesting sites for the House Sparrow, given its broad nesting niche. Most of the existing studies we have reviewed for example have carried out a directed search for House Sparrows/nests in buildings. This would reduce the possibility of detecting the House Sparrows accurate nesting range e.g. in vegetation and nests of other birds. Differences in small-scale habitat features could also contribute to differences in nesting availability and the impact of cavity reductions. For example, Summers-Smith (2003) suggests that the effect of reduced building cavities is likely to be more severe in areas that do not have alternative nesting opportunities (e.g. in cities with no hedges). As the House Sparrow is such a flexibly nesting species, it is evident that quantifying every potential nesting opportunity would be very difficult. Consequently, it will be difficult to convincingly determine that a decline in House Sparrow numbers is linked with nest site availability. Furthermore, given that housing deterioration is more likely in socially deprived areas it would be especially challenging to detect the effects of a reduced number of building cavities independently of other ecological factors, such as foraging opportunities and predation avoidance.

\section{Conclusion}

In this study, we have characterised nest-site selection of the House Sparrow in a population introduced to Australia just over 150 years ago. We report flexible 
Table 5 A summary of (a) studies inferring House Sparrow population trends from nest-site availability/selection surveys, and (b) studies focusing on population trends and nest site selection/availability

\begin{tabular}{|c|c|c|c|}
\hline References & Summary & Reasoning & $\begin{array}{l}\text { Weakness of the study in respect } \\
\text { to the conclusion drawn }\end{array}$ \\
\hline \multicolumn{4}{|l|}{ (a) } \\
\hline $\begin{array}{l}\text { Sziemer and Holzer (2005), } \\
\text { Shaw et al. (2008), Kumar } \\
\text { et al. (2015) }\end{array}$ & $\begin{array}{l}\text { High incidence of House Sparrow } \\
\text { breeding in low socio-economic } \\
\text { areas }\end{array}$ & $\begin{array}{l}\text { Low socio-economic areas have more } \\
\text { neglected buildings thus more nesting } \\
\text { opportunities }\end{array}$ & $\begin{array}{l}\text { No evidence of nest site limitation } \\
\text { in areas of high socio-economic } \\
\text { status. Low socio-economic areas } \\
\text { could attract House Sparrows } \\
\text { through alternative factors, e.g. } \\
\text { invertebrate abundance }\end{array}$ \\
\hline Wotton et al. (2002) & $\begin{array}{l}\text { House Sparrows are more abun- } \\
\text { dant in older building in rural, but } \\
\text { not (sub) urban areas }\end{array}$ & $\begin{array}{l}\text { Older, rural buildings are not renovated } \\
\text { thus have more crevices for nesting }\end{array}$ & $\begin{array}{l}\text { Public survey data overstates the } \\
\text { proportion of older, rural houses } \\
\text { available for nesting }\end{array}$ \\
\hline $\begin{array}{l}\text { Singh et al. (2013), Balaji } \\
(2014)\end{array}$ & $\begin{array}{l}\text { Fewer House Sparrows in urban } \\
\text { buildings }\end{array}$ & $\begin{array}{l}\text { Urban buildings are more renovated, thus } \\
\text { offer fewer nest sites than rural ones }\end{array}$ & $\begin{array}{l}\text { Studies assume urban areas are } \\
\text { more renovated than rural/sub- } \\
\text { urban ones without examining } \\
\text { the frequency of potential nest- } \\
\text { sites in the different settings }\end{array}$ \\
\hline \multicolumn{4}{|l|}{ (b) } \\
\hline Von Post and Smith (2015) & $\begin{array}{l}\text { Although House Sparrows show } \\
\text { a preference for nesting under } \\
\text { tiles, nest site availability is not a } \\
\text { critically limiting resource }\end{array}$ & $\begin{array}{l}\text { No relationship between the availability } \\
\text { and addition of preferred or artificial nest } \\
\text { sites affected population numbers }\end{array}$ & \\
\hline Wegrzynowicz (2012) & $\begin{array}{l}\text { Nest site availability does not affect } \\
\text { House Sparrow population trends }\end{array}$ & $\begin{array}{l}\text { No relationship between the number of } \\
\text { available nest sites and House Sparrow } \\
\text { population number }\end{array}$ & \\
\hline
\end{tabular}

nest site selection, and document a surprisingly high rate of nesting in vegetation (43\% of all nests were found woven into branches and stems rather than in cavities). The high rate of nesting in vegetation in Tasmania suggests that, contrary to numerous suggestions (e.g. Summers-Smith 2003; Shaw et al. 2008; Ghosh et al. 2010; Nath et al. 2016), House Sparrows may not be inherently dependent on cavities in buildings for nesting sites. Further, because the studied Australian House Sparrows have recently descended from European ancestors, our findings may suggest that House Sparrows in Europe are either already capable of constructing free-standing nests in vegetation (and perhaps this is not being examined or detected), or are likely to be able to shift their nesting niche in a relatively short period of time. Our findings emphasise the need for future work to examine the incidence of noncavity nesting in House Sparrows.

\section{Authors' contributions}

ELS and SCG conceived the idea; ELS carried out the fieldwork and analysis, ELS and SCG have both contributed to the writing of the manuscript. Both authors read and approved the final manuscript.

\section{Acknowledgements}

We would like to thank Eric Woehler, James Pay, and Bird Life Tasmania for their guidance throughout the project, Elissa Cameron and the University of Tasmania for their logistical assistance, and the landowners who provided access to their properties during field work. The research was supported by Australian
Research Council funding to SCG (FT130101253), and an MQRES Ph.D scholarship to ELS from Macquarie University.

\section{Competing interests}

The authors declare that they have no competing interests.

\section{Ethical standards}

The Animal Ethics committee at the Department of Biological Sciences, Macquarie University, approved our research.

Received: 23 June 2017 Accepted: 27 October 2017

Published online: 15 November 2017

\section{References}

Anderson TR. Biology of the ubiquitous House Sparrow: from genes to populations. Oxford (UK): Oxford University Press; 2006.

Andrew SC, Griffith SC. Inaccuracies in the history of a well-known introduction: a case study of the Australian House Sparrow (Passer domesticus). Avian Res. 2016;7:9.

Balaji S, Baskaran S, Rajan MK, Pavaraj M. Investigating the cause for the decline and strategies to conserve House Sparrow, Passer domesticus in Sivakasi Taluk, Virudhunagar district, Tamil Nadu, India. World J Zool. 2013:8:278-84

Balaji S. Artificial nest box for House Sparrow: an apt method to save the dwindling species in an urban environment. Int J Biodivers Conserv. 2014;6:194-8.

Barrows WB. The English Sparrow (Passer domesticus) in North America: especially in its relations to agriculture. Washington: Government Printing Office; 1889.

Bent AC. Life histories of North American blackbirds, orioles, tanagers, and allies. U.S. National Museum Bulletin. New York: Dover Publications; 1958. p. 1-549.

Burrage BR. A nesting study of the House Sparrow (Passer domesticus) in San Diego County, California. Trans Kansas Acad Sci. 1964;67:693-701. 
Chamberlain DE, Toms MP, Cleary-McHarg R, Banks AN. House Sparrow (Passer domesticus) habitat use in urbanised landscapes. J Ornithol. 2007; 148:453-62

Chmielewski S, Fijewski Z, Nawrocki P, Polak P, Sułek J, Tabor J, Wilniewczyc P. Birds of the Świętokrzyskie Mountains and their vicinity. The Faunistic Monograph. Poznań: Bogucki Wyd Nauk; 2005.

Crick HQP, Siriwardena GM. National trends in the breeding performance of House Sparrows Passer domesticus. In: Crick HQP, Robinson RA, Appleton GF, Clark NA, Rickard AD, editors. Investigation into the causes of decline of starlings and House Sparrows in Great Britain. BTO research report 290, DEFRA, Bristol; 2002.

Dandapat A, Banerjee D, Chakraborty DD. The case of the disappearing House Sparrow (Passer domesticus). Vet World. 2010;3:9.

Duckworth RA, Badyaev AV. Coupling of dispersal and aggression facilitates the rapid range expansion of a passerine birds. Proc Natl Acad Sci USA. 2007:104:15017-22

Ghosh S, Kim K, Bhattacharya R. A survey on House Sparrow population decline at Bandel, West Bengal, India. J Korean Ear Sci Soc. 2010;31:448-53.

Goyal M. Preliminary survey of House Sparrow (Passer domesticus) in three different areas of Haridwar, Uttaranchal. Dissertation; 2005.

Heij CJ. Comparative ecology of the House Sparrow Passer domesticus in rural, suburban and urban situations. PhD Thesis. Amsterdam: University of Amsterdam. 1985

Imboma TS. Ecological effects of the invasive House Sparrow (Passer domesticus) on sympatric native Sparrows in three urban areas in Kenya. Master's Thesis. Nairobi: University of Nairobi. 2014.

Indykiewicz P. Nests and nest-sites of the House Sparrow Passer domesticus (Linnaeus, 1758) in urban, suburban and rural environments. Acta Zool Crac. 1991;34:475-95

Ivanitzky W. Behavior of males and females of Indian Sparrow (Passer indicus) during nesting. J Zool. 1996;1996(75):249-55.

Kulczycki A, Mazur-Gierasinska M. Nesting of House Sparrow Passer domesticus (Linnaeus, 1758). Acta Zool Crac. 1968;9:231-50.

Kumar A, Kushwaha S, Kamaujia A. Rejoinder of House Sparrows (Passer domesticus) to artificial nest boxes in Lucknow District Uttar Pradesh India. Species. 2015;15:1-13.

Martin LB, Fitzgerald L. A taste for novelty in invading House Sparrows, Passer domesticus. Behav Ecol. 2005;16:702-7.

Morris FO, Tegetmeier WB. A natural history of the nests and eggs of British birds II. 4th ed. London: John C. Nimmo; 1896.

Nath A, Singha H, Panna D, Dasm AK, Lahkar BP. Nesting in a crowd: response of House Sparrow towards proximity to spatial cues in commercial zones of Guwahati city. Proc Zool Soc. 2016:69:249-54.

Paul RM. A review of House Sparrow population declines in India. Asia Pac J Res. 2015;1(29):38-40.

Peach WJ, Mallord JW, Ockendon N, Orsman CJ, Haines WG. Invertebrate prey availability limits reproductive success but not breeding population size in suburban House Sparrows Passer domestics. Ibis. 2015;157:601-13.

Pimentel D, Zuniga R, Morrison D. Update on the environmental and economic costs associated with alien-invasive species in the United States. Ecol Econ. 2005;52:273-88.
Pitman CR. Unusual nesting behaviour of the House Sparrow, Passer domesticus (L.). Bull Brit Ornithol Club. 1961;81:148-9.

Price JJ, Griffith SC. Open cup nests evolved from roofed nests in the early passerines. Proc R Soc B. 2017;284:20162708.

Robinson RA, Siriwardena GM, Crick HQP. Size and trends of the House Sparrow Passer domesticus population in Great Britain. Ibis. 2005;147:552-62.

Salek M, Riegert J, Grill S. House Sparrows (Passer domesticus) and Tree Sparrows (Passer montanus): fine scale distribution, population densities, and habitat selection in a Central European city. Acta Ornithol. 2015;50:221-32.

Schmidt G. Haussperling (Passer domesticus) als Felsholenbruter am Nordmeer. Vogelwelt. 1966;67:91-2.

Sharma SK. An unusual nesting site of House Sparrow Passer domesticus (Linn.). J Bombay Nat Hist Soc. 1995;92:422.

Shaw LM, Chamberlain D, Evans M. The House Sparrow, Passer domesticus in urban areas: reviewing a possible link between post decline distribution and human socioeconomic status. J Ornithol. 2008;2008(149):293-9.

Shochat E, Lerman SB, Anderies JM, Warren PS, Faeth SH, Nilon CH. Invasion, competition, and biodiversity loss in urban ecosystems. Bioscience. 2010:60:199-208.

Singh R, Kour DN, Ahmad F, Sahi DN. The causes of decline of House Sparrow (Passer domesticus, Linnaeus 1758) in urban and suburban areas of Jammu region, J \& K. Entomol Zool. 2013;8:803-11.

Summers-Smith D. Nest-site selection, pair formation and territory in the House Sparrow (Passer domesticus). Ibis. 1958;100:190-203.

Summers-Smith JD. The decline of the House Sparrow: a review. Brit Birds. 2003:96:439-46.

Summers-Smith JD. The house sparrow. London: Harper Collins Publications: 1963

Sziemer P, Holzer T. Vienna. In: Kelcey JG, Rheinwald G, editors. Birds in European cities. Germany: Ginster; 2005. p. 359-88.

Tatschl LJ. Unusual nesting site for House Sparrows. Auk. 1968;85:514.

Van der Elst D. Nidification du moineau danestique Passer domesticus dans les arbres en Wallonie. Aves. 1981;18:123-7.

Von Post M, Smith GH. Effects on rural House Sparrow and Tree Sparrow populations by experimental nest-site addition. J Ornithol. 2015;156:231-7.

Weber WC. House Sparrow nest in a revolving sign. Miss Kite. 1976;6(1):7-8.

Wegrzynowicz A. The use of nest-boxes by two species of Sparrows (Passer domesticus and P. montanus) with opposite trends of abundance the study in Warsaw. Int Stud Sparrows. 2012;36:18-29.

Werler E, Franks EC. Some unusual nest sites of the House Sparrow. Wilson Bull. 1975:87:113.

Wotton SR, Field R, Langston RHW, Gibbons DW. Homes for birds: the use of houses for nesting by birds in the UK. Brit Birds. 2002;95:586-92.

Wright TF, Eberhard JR, Hobson EA, Avery ML, Russello MA. Behavioural flexibility and species invasions: the adaptive flexibility hypothesis. Ethol Ecol Evol. 2010;22:393-404.

\section{Submit your next manuscript to BioMed Central and we will help you at every step:}

- We accept pre-submission inquiries

- Our selector tool helps you to find the most relevant journal

- We provide round the clock customer support

- Convenient online submission

- Thorough peer review

- Inclusion in PubMed and all major indexing services

- Maximum visibility for your research

Submit your manuscript at www.biomedcentral com/submit
C BioMed Central 